\title{
Using Statistics to Analyze Anthropological/Religious Issues from the Distant Past
}

\author{
Walter R Schumm ${ }^{1 *}$, Duane W Crawford ${ }^{1}$, Paul E. Barkey, PhD', Daniel Bush ${ }^{2}$ and Daniel \\ W. Bosch ${ }^{2}$
}

${ }^{1}$ Department of Applied Family Sciences, College of Health and Human Sciences, Kansas State University, USA

${ }^{2}$ Private Consultant, Kansas, USA

\begin{abstract}
Careful use of basic statistics may allow scholars to bring a more systematic approach to understanding open questions from past cultures or cultures in conflict. Here, we bring relatively simple statistics to bear on four issues from past times. First, we look at part of the clash between Native American and U.S./Mexican cultures about 1850, as one medical doctor attended to the wounded from the related battles. We test the relative severity of different types of arrow wounds. Second, we bring statistics to bear on the issue of variant New Testament texts and test comparative hypotheses about variances in chapter 16 of Paul's letter to the Romans. Our last two examples use data from the infancy narratives about Jesus from the gospels of Matthew and Luke to test "source" and "audience" hypotheses by examining specific types of content in both. Our overall results demonstrate how statistics can be useful in unexpected historical analyses of ancient cultures, an encouragement for other scholars to apply such techniques to other contested theories.
\end{abstract}

\section{Keywords}

Native Americans, Arrow wounds, Medical treatment, The letter to the Romans, Scripture variations, Gender, Matthew, Luke, Mary, Joseph, Infancy narratives, Statistics and History

\section{Introduction}

Today's scholars are familiar with the use of statistics to analyze data from field studies or social surveys. Scholars may be less familiar with the use of statistics to test data collected before the advent of statistics. Here we use three examples of how statistics may be brought to bear on issues from the past - survival rates from arrow wounds from native American/U.S./Mexican conflicts prior to 1860 , the analysis of variant texts in early Christian literature, and an analysis of the role of gender and personal reflections in infancy narratives about Jesus in the gospels of Matthew and Luke, testing both "source" and "audience" hypotheses. The correct use of statistics can enrich our understanding of past events and possibly help solve issues that have been mysteries for centuries.

First Example: Arrow Wounds (circa 1850 C.E.)

\section{Introduction}

Bill [1] wrote an extensive article on the treatment of arrow wounds, based on his experience as a surgeon with the Army on the U.S. and Mexican frontiers. His paper refutes much of what we might remember from old movies about that time. Bill notes that an expert Native American archer could release up to six arrows a minute, a rate at least twice as fast as the soldier with a musket could reload and fire before the advent of repeating rifles. Even though there were repeating revolvers after 1836 (thanks to Samuel Colt), the effective range of the bow was probably greater than that of the early pistols.

Bill observed that well-placed arrows could be more lethal than gunshot wounds for several reasons. First, almost all the wounded he treated had wounds from more than one arrow due to the high rate of fire from their opponents. Second, while bullets would bruise tissue, their heat in flight would tend to cauterize tissue and slow bleeding, arrowheads would cut blood vessels and lead to more blood loss and a higher risk of infection (without antibiotics, of course). Thus, Native

*Corresponding author: Walter R. Schumm, Emeritus Professor, Department of Applied Human Sciences, College of Health and Human Sciences, Kansas State University, USA

Accepted: March 25, 2021

Published online: March 27, 2021

Citation: Schumm WR, Crawford DW, Barkey PE, et al. (2021) Using Statistics to Analyze Anthropological/Religious Issues from the Distant Past. Insights Anthropol 5(1):337-346 
Americans were a more capable military force than one educated by Hollywood might imagine.

Extraction of arrowheads was often more difficult as pulling a round ball out would not do much more damage but pulling out a sharp arrowhead could continue to cut nerves and blood vessels further. Removal of an arrowhead was better done with the shaft left in place as the surgeon could find the arrowhead by following the shaft; without a shaft to follow, finding the arrowhead became a matter of some guesswork, which delayed treatment and could cause additional tissue damage.

\section{Data}

When arrows entered the spine, brain, intestines, heart, or lungs (27 cases) survival rates appeared lower than when they did not penetrate those areas (53 cases), with survival rates of $11.1 \%$ versus $90.6 \%$, respectively. However, the chisquare test was not invented for testing such data until 1904 by Karl Pearson; thus, Bill could not evaluate his data to determine if they were possibly a result of random chance, even though in the seventeen cases in which the heart or intestine were wounded by an arrow, all the patients died.

\section{Results}

The difference might seem impressive but might it not be due to random effects? That is what statistics can do for us test whether such differences were likely a result of chance factors. Using a $2 \times 2$ cross tabulation of type of injury by survival/non-survival, the chi-square test value was 48.87 with one degree of freedom $(p<0.001)$. The zero-order Pearson correlation was $r=0.78(p<0.001)$. The odds ratio was 76.80 (95\% Cl, 16.92-348.66, $p<0.001)$. Statistics, regardless of type, all indicate the greater lethality of arrow wounds that involved penetration of key organs.

\section{Discussion}

One implication would be that arrows were nothing to disregard in battle; they could be just as fatal as gunshot or saber wounds. A second implication would be that a wise soldier might improvise some type of armor/leather protection for his abdomen as the most efficient way to improve his chances of survival, especially if cover behind defensive positions was not available. A third implication would have been that if you have to stop an arrow with your leg or arm to prevent it from hitting your vitals, that would be a good trade-off in most cases. A further thought would be that a spent arrow might not damage your head severely, but otherwise a quick move of your head to avert the impact of an arrow that might have enough impact to penetrate your skull would greatly increase your chance of survival. Lastly, one can imagine the fear of the soldier/citizen facing a host of incoming arrows whereby the chances were great of receiving multiple wounds nearly simultaneously; one could easily be rendered useless as a combatant very quickly regardless of your skill as a rifle marksman. In summary, the use of statistics with older data can reveal to us some useful detailed information about the clash of cultures on the American frontier over 150 years ago.

\section{Example 2: Variations in Ancient Documents}

\section{Introduction}

It is well known the early Christian materials have a number of variants. While many of these are minor in size and content, some are larger. One example is the number of variations in the ending of the letter to the Romans by the apostle Paul. A number of reasons for these variations have been proposed. If one had to prepare an important letter that might be of interest to more than one audience, there were two ways to deliver it to multiple groups. One way would be to have the letter passed around, which we know Paul requested at least once (Colossians 4: 16). A second way would be to have copies made of the same letter, possibly appending different greetings for different intended recipients, and send the copies to different locations via different messengers.

With respect to the different endings of the epistle to the Romans, Manson ([2] pp. 230-241) argued, in an adaptation of ideas from David Schulz of 1829, that Romans 16, its last chapter, was probably a letter of introduction for Phoebe, who was not acquainted with the believers at Ephesus and was taking a copy of Romans 1-15 to the Ephesian church. Harrison ([3] pp. 310) regarded Manson's 1962 hypothesis as "equally probable" to the hypothesis that Romans 16 was included as part of the original epistle to the church at Rome. Lohse ([4] pp. 78-79) said that many scholars agree with Manson's hypothesis but concluded that his "thesis is not absolutely certain." Perrin ([5] pp. 114) argued that "Modern scholarship is mostly of the opinion that Paul ... had a copy sent to Ephesus, with these greetings added."

Hiebert [6] said that "There is considerable to be said for this Ephesian hypothesis; it has received widespread support" (p. 173). Nevertheless, Hiebert ([6] pp. 173) concluded that "The balance of evidence seems definitely in favor of Romans 16 as part of the original letter.... We reject the view that the chapter is a separate letter to the Ephesians...". In support, Fiensy ([7] pp. 230) argued that "most scholars now accept the authenticity of Romans 15 and 16." It is clear that a range of scholarly opinion has existed on the issue of Romans 16 , with perhaps a trend in more recent years away from support for the Ephesian hypothesis. As with any historical, even ancient, documents of anthropological interest, one must ask if statistics can be of help in solving questions under review. There is no doubt that it would have been possible for Paul to prepare a copy for Rome and a copy for Ephesus, if he wished. The question that statistics may help with is whether it was probable that he did so.

\section{Data}

A review was made of several commentaries and a list of separate arguments made pro and con for the Ephesian versus Roman hypotheses concerning the original intended destination of Romans XVI. We treated the situation as one in which there are two models to be evaluated, with indications possible for either or both of the models. When an indication is presented by a commentator in favor of either model, a "YES" vote or indication was recorded in favor of that model. When an argument might fit both hypotheses we categorized 
Citation: Schumm WR, Crawford DW, Barkey PE, et al. (2021) Using Statistics to Analyze Anthropological/Religious Issues from the Distant Past. Insights Anthropol 5(1):337-346

it with the Roman hypothesis, notated with a question mark, to try to reduce the risk of confirmation bias on our part [8]. The results of the review are presented in Table 1 . The first author prepared the table, which was reviewed and checked by the second through fifth authors, who agreed with the coding used by the first author.

\section{Analysis}

Are previous commentators correct when they argue that the weight of evidence is equal or in favor of the Roman hy-

Table 1: Comparative indicators supporting ephesus versus rome as the destination for chapter 16 of the epistle to the romans.

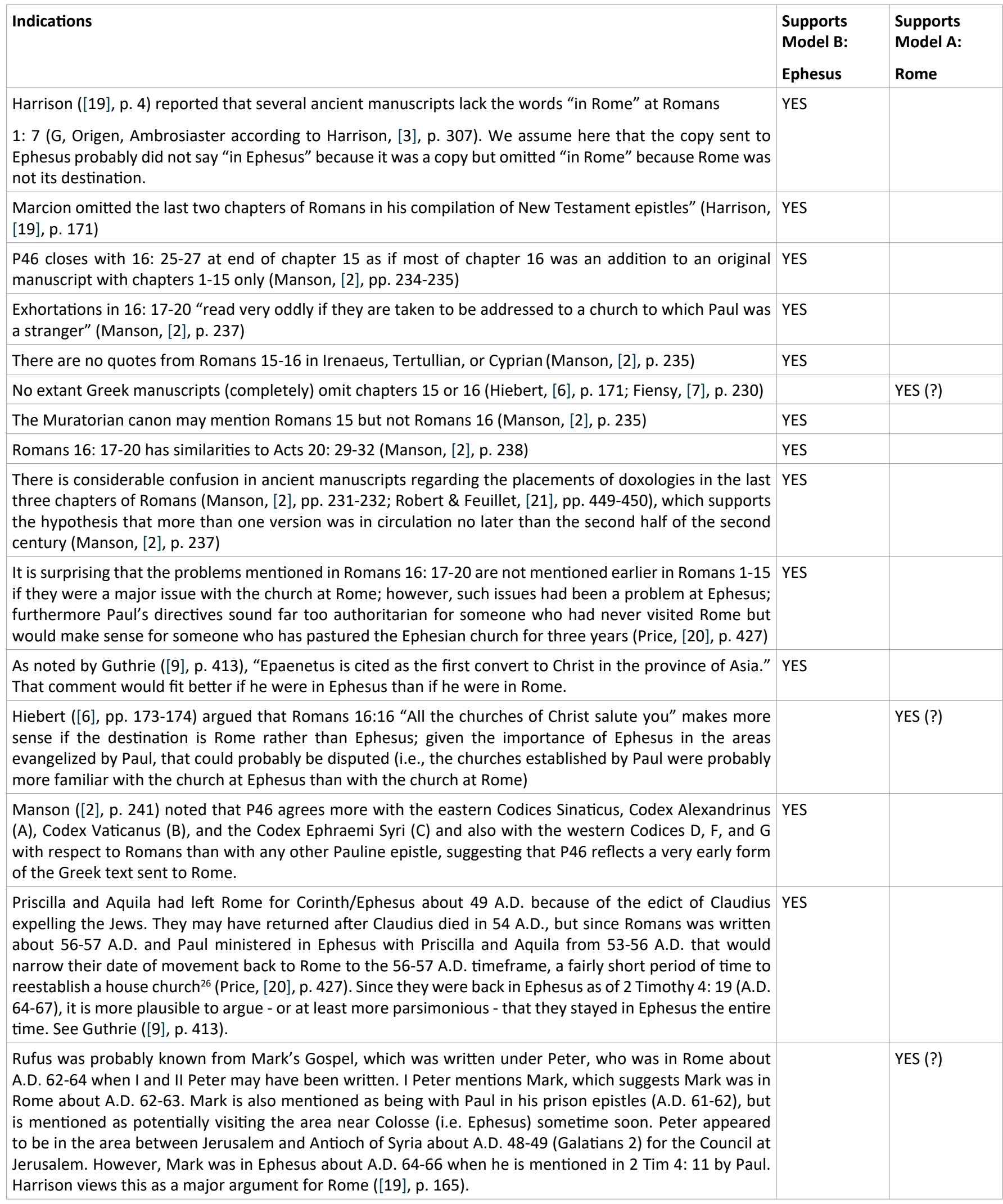


To counter the above argument, it can be noted that if Rufus was in Rome with Mark and Peter as of A.D. YES 57 , it might have seemed peculiar for Paul to highlight a relatively unknown Christian and at the same time omit mention of the much better known Mark and Peter, both of whom Paul had met or worked closely with. That is why Pfeiffer \& Harrison ([19], p. 1179) say that "If Peter had been at Rome when Paul wrote this epistle, Paul certainly would have sent him greetings. Paul's longstanding desire to preach in Rome (Rom 1: 11-13) and his policy of not building on another man's foundation (15: 20) make it seem unlikely that Peter was even in Rome before the time of the writing of Romans." Paul's relatively unfavorable comments on Peter and his experiences with Mark were several years previous. If Rufus was at Rome, it seems strange that Paul mentions Mark in his prison epistles but omits greetings from Rufus (if Rufus and Mark and Paul were that close as Harrison implies)

If all the people mentioned in Romans 16 were indeed at Rome as of A.D. 57 and if Paul reached Rome in YES A.D. 60-61, it is very strange that none of them greeted him when he arrived at Rome - or at least they are not mentioned by name (Acts 28: 15).

If Paul had a large contingent of close supporters at Rome, it seems unusual that Peter - at Rome - would YES describe Paul's writings as strange and difficult (2 Peter 3: 16); in fact, Paul discusses apparent enemies at Rome some years later (Philippians 1: 15-16, A. D. 59-61), which would be surprising if he had such a large contingent of as many as seven house churches in Rome as early as A. D. 56 or 57 (Fiensy, [7], p. 230).

Is it more plausible that Paul would be able to describe the following from a place he had lived for three YES years (A.D. 53-56) right before Romans was written or with respect to a place he had never yet visited? ${ }^{30}$

Several house churches of Christians

Two Christians who had been in prison with him

Three fellow workers

His first convert in the area around Ephesus

Three people he loved or had a close relationship with

Five people of whom he had knowledge of their work or character

Eleven or twelve persons whom he knows by name even though

nothing special is mentioned about their character, work, or close

relationship with Paul

Harrison observed that travel to Rome from Ephesus was easy and quite possible ([19], p. 162); however, travel could go both ways and former servants of the Emperor could have traveled to Ephesus to partake of the fellowship there. However, the similarity of names mentioned by Paul, especially Herodian and members of the household of Aristobulus, tends to support a Roman destination, even though an argument could be made that the common names might have just as easily been found in Ephesus (nevertheless, this is counted as an indication for model A)

Paul's favorable comments to selected individuals would have seem like playing favorites if written to Ephesus (Harrison, [19], p. 163); however, the comments could have served as a list of key people to meet when Phoebe visited Ephesus (with something about why each was important; see Manson, [2], p. 238 and Price, [20], p. 428 for the idea that Phoebe took the letter to Ephesus). We would argue that saying you "love Ampliatus in the Lord" and not mention others would be more risky in a church with which you were unfamiliar; in contrast, if a church were very familiar with you, you could make such distinctions more safely. However, We would counter that partiality was avoided by Paul's mentioning such a large number of individuals (if everyone who might expect to be mentioned is mentioned that would tend to reduce the risk of appearing partial). In spite of our doubts, we have counted this as an indication for Model A.

Phoebe may have been going to raise funds for Paul's trip to Jerusalem but that could have been true whether she was going to Rome or to Ephesus. Phoebe might just as well have been unfamiliar with the Ephesian churches and in need of their support either for herself or to help raise funds for Paul's expedition to the West. Since Paul planned to visit Ephesus, but only briefly, en route to Jerusalem, would not his best hope of raising funds immediately come from Ephesus, especially given the uncertainties of his future? For sake of argument, though, we will count this as an argument for Rome as the destination for chapter 16, even though it might be that Romans 16: 1-2 was sent to Rome and Romans 16: 3-27 was sent to Ephesus (Guthrie, 1990, p. 415).

The warnings in Romans 16: 17-19 “... appear to be against a form of antinomianism which is known to have YES thrived at Ephesus." (Guthrie, [9], p. 413).

Hiebert ([6], p. 173) argued that Paul never sent personal greetings to a church with which he was familiar but did send greetings to people he knew in churches he had never visited (However, this argument was disputed previously, but we are still counting it as an indication for Model A) 
Citation: Schumm WR, Crawford DW, Barkey PE, et al. (2021) Using Statistics to Analyze Anthropological/Religious Issues from the Distant Past. Insights Anthropol 5(1):337-346

Peter was known to have been at Rome, at least later, and probably wrote his Epistles from Rome. If he YES knew that Paul's epistle to the Romans had also been sent to Asia Minor and given that parts of Romans are among the most difficult of Paul's writings, Romans may be what is referred to in 2 Peter 3: 15-16 (which relieves Hebrews of the burden of supporting Peter's comment, which agrees with most recent scholarship that denies Pauline authorship of Hebrews)

Hiebert argued that sending a letter consisting "almost entirely of greetings" would have been "a YES monstrosity," that "The ancients would not have thought of writing such a letter." However, Lohse provided evidence that such letters were written in ancient times, lending support to the possibility of Paul preparing such a letter.

pothesis? Statistics will allow us to evaluate, with more than subjective opinion, whether the odds really are equal or in favor of the Roman or Ephesian hypotheses. Furthermore, we can adjust our results to determine how robust the results may be; that is, how far wrong can our arguments be before we might need to change our conclusions? The one-sample chi-square test allows a test of whether a distribution of events is evenly divided across the range of events. When there are two possibilities, the most common test is against each event representing $50 \%$ of the distribution. A significant chi-square test indicates a significant deviation from a 50/50 distribution, indicating that one type of event is more frequent than the other. Events may be occurrences of ideas, allowing the evaluation of relative predominance of outcomes in debated issues.

\section{Results}

The chi-square test for a $17 / 6$ split (or a $6 / 17$ split) would yield a value of $5.26(p<0.03)$, indicating a rejection of the balanced (50/50) distribution. Statistically, if one accepts most of the arguments on either side listed in Table 1, the weight of the data tend to support Manson's Ephesian hypothesis, given the $19 / 7$ split in Table 1 , with a chi-square value of $5.54(p<0.019)$. How robust are these results? First, we counted ambiguous results in favor of the Roman hypothesis. Even so, we could discard three items in favor of the Ephesian hypothesis and find nearly significant results $(p=0.06)$. We could add two more items in favor of the Romans hypothesis and obtain similar results $(p=0.059)$. Discarding two Ephesian items $(p=0.04)$ or adding one Romans item $(p=0.034)$ would retain our significant results. More importantly, if our results reject the equality hypothesis, they more substantially refute the theory that the Roman hypothesis was more likely to be correct. The weight of evidence, as evaluated statistically, appears to support Manson's Ephesian hypothesis, despite the recent statements to the contrary by Fiensy [7], Guthrie ([9] pp. 427), and Hiebert [6]. The bottom line is that the Ephesian hypothesis has at least equal, if not more, merit statistically than the Roman hypothesis.

\section{Discussion}

If the Ephesian hypothesis is correct, we have a very detailed review of the key house churches and their members and leaders as Paul remembered them from his recent threeyear ministry in Ephesus. One possibility that was not encountered in our review of the literature was that perhaps Paul often wrote personal greetings to his churches, but because they were appended to his letters (and primarily for use by his couriers rather than to make theological statements of the kind in his formal letters) rather than contained in them, most of them have been lost, with the exception of Romans 16 . How likely would it be that Paul had such a great heart for only the people and the church mentioned in Romans 16? I think it is more likely that he had such a heart for all his churches and friends and wrote similar notes of appreciation to more of them (but his notes were not preserved). That would suggest that Romans 16 is but a wonderful preserved sample of the type of things he wrote personally, not the only one that he ever wrote. If so, the descriptions of house churches, leaders, and members of the church cited by Paul at Ephesus give us a detailed picture of that church not long after Paul had completed his three-year ministry there. Paul mentions at least nine women and no more than 19 men in that church, a result not quite significantly different by gender percentages $(p<$ $0.06)$, indicating the great importance of women in the early Christian churches.

\section{Example 3: Ancient Birth Narratives of Jesus Introduction}

A cursory reading of the early chapters in the gospels of Matthew and Luke will reveal that the Christmas stories, otherwise known as "infancy or birth" narratives [10] differ. One way they differ is in terms of their genealogies [11], but that is beyond the scope of our research here. According to Isaacs ([10] pp. 80) "most scholars are agreed that Luke's infancy narrative is independent from that found in Matthew" (p. 80). Why might that be?

One argument is that Matthew (1:18 to $2: 23)$ and Luke (1:5 to 2: 52 ) had different objectives and selected (or even fabricated) events that fit their objectives, mainly related to having Jewish (Matthew) or Greek/Roman (Luke) audiences, which we label the "audience" hypothesis. Another possibility, the "source" hypothesis, the hypothesis that we will examine, is that Matthew used Joseph (or his household, possibly including among others - James and Jude, who wrote New Testament epistles) as a source, while Luke used Mary (or her household, possibly including John) as his primary source. Brown [12] argued that most scholars did not think that the genealogies were actual family trees (p. 89), although he acknowledged that some thought that Joseph was responsible for the geneology in Matthew and Mary for the one in Luke (p. 90). Later, Perkins ([13] pp. 300) claimed that Matthew's version focused on Joseph, while Luke's focused on Mary (p. 
298). Luke did say that he investigated matters carefully and probably did have access to Mary at some point between Jerusalem and Ephesus when he was with Paul; tradition places Mary eventually with John in Ephesus. For example, both hypotheses might have some degree of validity. Below, we will attempt to set up criteria that might reflect the memories of Joseph versus those of Mary to see if one set occurs more in Matthew and the other more in Luke, to test the Joseph versus Mary source hypothesis. One might do a similar analysis based on preferences of Roman/Greek audiences (e.g. information on Roman authorities involved in the birth story) versus Jewish audiences (e.g., information on Jewish authorities) but that is beyond the scope of this report. While the household was a useful level of analysis for ancient families [14], in this analysis we will use an individual level of analysis for our measurement and our statistics. While in the past we have received negative reviews when using statistics to study questions involving religion, directly or indirectly, we want to be willing to challenge conventional approaches to studying issues in social science and/or religion in hopes of finding results that might not be detectable with other methods [15].

\section{Measures}

Do the different birth narratives "fit" the perspectives of male (i.e., Joseph or his sons) versus female (i.e., Mary, his mother) relatives of Jesus? By perspectives we would include gendered ways of looking at life but also seeing things from one's own personal perspective since everyone sees life through one's own eyes rather than someone else's and furthermore interprets what is seen through personal filters.

There are many potential indicators of who might have provided someone else with information.

\section{Mention of formal names}

First, if a person $\mathrm{X}$ is providing information about situations with which $X$ is familiar, we think it is likely that $X$ will refer to himself, even by name, or the recorder of what $X$ says may add $X$ 's name to statements made by $X$. So, if $X$ says "My boat sank in the storm" the recorder might record that " $X$ 's boat sank in the storm" using X's name. If two other persons were in the same boat, we think it's more likely that $X$ will talk about the situation from his/her own perspective rather than from the perspective of the other two persons, thus, leading to $X^{\prime}$ 's name being mentioned more often than if the other two persons were narrating the story about the boat and the storm. Thus, the recorder might tend to say that " $X$ was in the boat when it sank as were two friends (not named)". Thus, if a person is mentioned by name more often in a narrative, then we think it is plausible to argue that that person may have been the author or provider of information for the narrative. Brown [12] acknowledges that it appears that mention of Joseph appears more often than Mary in Matthew's account while the reverse is true in Luke's account (p. 35), though he seems to regard that as insufficient information from which to draw any conclusions, with which we agree - which is why we are using other criteria as well. Others have noted the increased focus on Mary in Luke [16], but noticing a possible pattern is not the same as testing a hypothetical pattern statistically.

\section{Mention of events/perceptions available only to the source}

If I have a dream and tell someone about it, it's likely that I am talking about my dream, not someone else's, especially the more specific the details may be. If I have a life event and provide much detail about it or provide details only I would tend to know or find salient, then it is likely that I wrote it or provided the information. For example, suppose there are two people involved and the dream of one person $(X)$ is discussed in detail while the dream of $Y$ is given scant mention. Who probably wrote the story? We would suggest that $X$ is more likely the source since it is more likely that $X$ will remember their own dream in detail rather than remembering Y's dream. While dreams are obviously internal mental events, most perceptions are also and the more detailed the recollection, the more likely it would have come from the same person who had those perceptions. This would include a report of feelings. If person $X$ was reported to have been afraid, that report would have been more likely from $X$ than from $Y$ who might not have been exposed to the same fearful threat. Likewise, if there is a report that $X$ was planning on doing something that $Y$ might not have known about, it is more likely that the report came from $X$ since $X$ 's mental plans might not have been known by $Y$ or shared with $Y$ by $X$.

\section{Gendered saliences}

We think that men and women may tend to remember their own gendered experiences with more detail than those of persons of other gender(s). For example, who would be more likely to remember when her baby first kicked in her womb - the mother herself or her husband? We think it would be the mother. If a man lived in a society where the man was expected to protect/defend his wife and they were attacked by bandits, whom the man drove off, we think the man would be more likely to remember more of the details of such a story since he would have likely thought it to be a fulfillment of his responsibilities toward his wife.

\section{Receipt of conversations}

We think that if a person $C$ speaks to person $X$ directly, that person $X$ would be more likely to remember the conversation than would a person $Y$ who either didn't hear it at all or only heard about it secondhand or indirectly. Thus, if a conversation is reported from person $C$ to person $X$, we would suspect that person $X$ was reporting it, especially if the report was very detailed. If person $C$ and $A$ are reported to have had a detailed conversation and it's not even clear if person $Y$ was present, we think it's likely that the detailed report of the conversation came from $\mathrm{C}$ or $\mathrm{A}$ rather than from $\mathrm{Y}$.

\section{Neutral indicators}

Some indicators may be so general that they will not help pinpoint a source. For example, if it was mentioned that a baby was born when President Bush was president of the United States, that may not tell us much because both the mother and father may well have known who was president at the time. If a well known person died at some point, the mere mention of that fact may not tell us much about the 
source, since it was likely known and could have been reported by many people. Another neutral situation may be when both persons $\mathrm{X}$ and $\mathrm{Y}$ are mentioned by name in a narrative at the same time. That might mean that both $X$ and $Y$ were sources or that either $X$ or $Y$ remembered that both $X$ and $Y$ were present together at that particular time; either way, that clue doesn't help us decide whether $X$ or $Y$ was the primary source of the material.

\section{Data}

There are gender-related criteria for instances in which we think either a man or a woman would be more likely to have seen an event as salient or memorable from the perspective of their own gender. However, some events or memories would be gender or person neutral, such as who was king at the time (how they kept time with no universal cal- endar), or when an event is discussed that both the husband and wife attended. Thus, there are neutral criteria where we do not think narratives would distinguish between two sources of authorship. These would include when a person or persons are aware of something in general that the general public would have known about or could have seen directly, for example: Herod's death (Matthew 2: 19; Matthew 2: 22; Archelaus replacing his father Herod in Judea; the wise men visiting Herod in Jerusalem, Matthew 2: 1-9; and Herod killing children, Matthew 2: 16-18. Other neutral criteria would include when both Mary and Joseph were mentioned together in same verse by name (Matthew 1: 18, 20; Luke 1: 27; 2: $16)$ or when both Mary and Joseph were warned by God in a dream, and both departed for Egypt at night (Matthew 2: 12), or when both Mary and Joseph went to Bethlehem (Luke 2: 4-5). Another neutral example is when both Mary and Jo-

Table 2: Personal Perspective Criteria for Authorship of Birth Narratives of Jesus.

\begin{tabular}{|c|c|c|}
\hline Criteria & Matthew & Luke \\
\hline $\begin{array}{l}\text { If an event happened to person } X \text {, they } \\
\text { would be more likely to recall/report it than } \\
\text { if person } Y \text { were recalling that the event } \\
\text { happened to person } X \text {. }\end{array}$ & $\begin{array}{l}\text { 1: } 18 \text { Mary was pregnant }\left({ }^{*}\right) \\
\text { 2: } 11 \text { Mary visited by Wise Men }\left(^{*}\right)\end{array}$ & $\begin{array}{l}\text { 1: } 39 \text { Mary visited Elisabeth } \\
\text { 2: } 34 \text { Simeon spoke to Mary }\end{array}$ \\
\hline $\begin{array}{l}\text { One person is mentioned by name while the } \\
\text { other person is not. }\end{array}$ & $\begin{array}{l}\text { 2: } 13,14,20,21 \text { (four times, Mary is cited } \\
\text { only as Jesus's mother, not by her name) } \\
\text { 2: } 23 \text { (Joseph is said to dwell in Nazareth but } \\
\text { Mary not mentioned with him, though it's } \\
\text { inferred) }\end{array}$ & $\begin{array}{l}\text { 1: } 19 \text { Mary pondered all these things in her } \\
\text { heart } \\
\text { 1: } 33 \text { Joseph mentioned by name, Mary not } \\
\text { so }{\left({ }^{*}\right)}^{\text {2: } 34 \text { Mary mentioned alone by Simeon }}\end{array}$ \\
\hline $\begin{array}{l}\text { Person } \mathrm{X} \text { had a dream with specific content } \\
\text { mentioned as a person would be more } \\
\text { likely to recall/report their own dream as } \\
\text { compared to someone else's dream }\end{array}$ & $\begin{array}{l}\text { 2: } 22 \text { Joseph warned by God in a dream to } \\
\text { go to Galilee }\end{array}$ & \\
\hline $\begin{array}{l}\text { Person } X \text { was visited by an angel/God and } \\
\text { what the angel/God said specifically is } \\
\text { recalled/reported }\end{array}$ & $\begin{array}{l}\text { Joseph visited by an angel with a specific } \\
\text { message (1: } 20-21) \\
\text { Joseph visited again by an angel with a } \\
\text { message to leave town (2: } 13) \\
\text { Joseph visited by an angel a third time, to } \\
\text { return (2: 19-20) }\end{array}$ & $\begin{array}{l}\text { Luke 1: } 28 \text { (Mary visited by an angel, who } \\
\text { said a lot) }\end{array}$ \\
\hline $\begin{array}{l}\text { Person } X \text { mentioned by name } \\
\text { (not as a couple) }\end{array}$ & $\begin{array}{l}\text { 1:19 Then Joseph her husband } \\
\text { 1: } 24 \text { Then Joseph waking up... } \\
\text { 2: } 11 \text { the wise men saw the child with Mary } \\
\text { his mother (Joseph not mentioned in the } \\
\text { scene) }\left(^{*}\right)\end{array}$ & $\begin{array}{l}\text { Luke 1: } 30 \text { (Angel mentions Mary by name) } \\
\text { Luke 1: } 34 \text { (Mary mentioned by name) } \\
\text { Luke 1: } 38,39,41,46,56 \text { (Mary mentioned } \\
\text { by name without Joseph's name mentioned) } \\
\text { 2: } 33,43 \text { (Joseph's name mentioned, not } \\
\text { Mary's) (') }\end{array}$ \\
\hline $\begin{array}{l}\text { Person } \mathrm{X} \text { engaged in actions/thoughts/ } \\
\text { speech only person X would know about }\end{array}$ & $\begin{array}{l}\text { 1:19 Was considering putting her away } \\
\text { privately } \\
\text { 1: } 19 \text { While he thought on these things } \\
\text { 1:25 And knew her not until she had given } \\
\text { birth } \\
\text { 2: } 22 \text { Joseph was afraid }\end{array}$ & $\begin{array}{l}\text { 1: } 19 \text { Mary kept all these things in her heart } \\
\text { 1: } 29 \text { Mary was troubled and wondered } \\
\text { about the greeting from the angel } \\
\text { 1: } 38 \text { (Mary's speech in detail) } \\
\text { 1: } 46-55 \text { (Mary's magnificat) } \\
\text { 2: } 35 \text { (Simeon's detailed conversation with } \\
\text { Mary) } \\
\text { 2: } 48 \text { (Mary's conversation with Jesus at age } \\
\text { 12) }\end{array}$ \\
\hline
\end{tabular}

$(*)$ Evidence does not fit hypothesis. 
seph were looking for the "lost" Jesus (Luke 2: 45). The data were coded by the first author but checked and confirmed, with one exception, by the second through fifth authors. The fifth author suggested that the details provided about Mary's conversation with Jesus (Luke 2: 48) would count in favor of Luke's using Mary as a source for his gospel, with which we all have agreed.

\section{Results}

With data from Table 2, we have Matthew featuring 14 indications for Joseph and 3 for Mary while Luke had 2 and 18 , respectively, yielding a significant $(p<0.001)$ chi-square $(d f=1)$ result of 19.60 , with $p<0.001$ for a two-sided Fisher's Exact test, a Pearson correlation of $0.728(p<0.001)$, and an odds ratio of 42.00 ( $p<0.001,95 \% \mathrm{Cl}$ of 6.15 to 286.68). Data from Table 3, have Matthew with 6 indications for Joseph and Luke with 9 indications for Mary, yielding a chi-square of 15.00 ( $d f=1, p<0.001$ ) with $p<0.001$ for a two-sided Fisher's Exact test and a Pearson correlation of $1.00(p<0.001)$. Combining the two sets of data yielded, from Matthew, 20 indications for Joseph and 3 for Mary, with 2 and 27 for Luke, yielding a chi-square $(d f=1)$ value of $33.68(p<0.001), p<$ 0.001 for a two-sided Fisher's Exact test, a correlation of .805 $(p<0.001)$, and an odds ratio of 90.00 ( $p<0.001,95 \% \mathrm{Cl}$ of 13.73 to 590.00$)$. How robust are those results? First, because of overlap, we did not add another indication for Mary from Luke 2:48 where Mary's words to Jesus about his getting "lost" in the temple are recalled, so our present results may be conservative. Although, as noted, we may have missed some indications that support the hypothesis more strongly, we could switch out seven indicators in Matthew (seven fewer for Joseph and seven more for Mary) and six indicators

Table 3: Gender-related Criteria for Authorship of the Birth Narratives of Jesus.

\begin{tabular}{|c|c|c|}
\hline Issues & Matthew & Luke \\
\hline \multicolumn{3}{|l|}{$\begin{array}{l}\text { Things a man might be more likely to recall/ } \\
\text { report }\end{array}$} \\
\hline What dignitaries did & Matthew 2: 11 (Wise men visited) & \\
\hline $\begin{array}{l}\text { What happened that provided family with } \\
\text { provision }\end{array}$ & $\begin{array}{l}\text { Matthew 2: } 11 \text { (Wise men brought gold and } \\
\text { other valuables, which served to pay for the } \\
\text { emergency trip to Egypt, if not the long stay } \\
\text { there) }\end{array}$ & \\
\hline $\begin{array}{l}\text { More likely who will note it when any male } \\
\text { doesn't get the honor he thinks he should } \\
\text { (a man gets snubbed or a woman gets the } \\
\text { honor instead) }\end{array}$ & $\begin{array}{l}\text { Matthew 2: } 16 \text { (Herod's anger) } \\
\text { Matthew 2: } 11 \text { (Wise men didn't worship } \\
\text { Joseph but focused on Mary and Jesus, } \\
\text { Joseph might have felt slighted, if he were } \\
\text { there at the time) }\end{array}$ & \\
\hline $\begin{array}{l}\text { More likely to remember visitors who are } \\
\text { more significant in the social hierarchy of } \\
\text { that day }\end{array}$ & Matthew 2: 11 (Wise men, of high status) & \\
\hline $\begin{array}{l}\text { More likely to remember not having sex with } \\
\text { his wife (Catholics and Protestants disagree } \\
\text { on whether or not Mary was a perpetual } \\
\text { virgin) }\end{array}$ & $\begin{array}{l}\text { Matthew 1: } 25 \text { (Joseph knew her not until } \\
\text { after Jesus was born) }\end{array}$ & \\
\hline \multicolumn{3}{|l|}{$\begin{array}{l}\text { Things a woman might be more likely to } \\
\text { recall/report }\end{array}$} \\
\hline Place in house where your baby was born & & Luke 2: 7 (guestroom full) \\
\hline Type of crib used for baby & & Luke 2: 7 (manger) \\
\hline Type of baby clothes worn & & Luke 2: 7 (swaddling clothes) \\
\hline $\begin{array}{l}\text { Conversations with other female relatives or } \\
\text { women encountered }\end{array}$ & & $\begin{array}{l}\text { Luke 1: } 40-45 \text { (Mary talks with Elisabeth) } \\
\text { Luke 2: } 37 \text { (Age of Anna remembered but } \\
\text { not exact age of Simeon) }\end{array}$ \\
\hline $\begin{array}{l}\text { How long one woman spent time with } \\
\text { another woman }\end{array}$ & & Luke 1: 56 (three months) \\
\hline Concerned with lost/missing child & & Luke 2: 45 (Jesus is missing) \\
\hline $\begin{array}{l}\text { More likely to remember visitors (to one's } \\
\text { temporary home or during your travels away } \\
\text { from home) who are insignificant in the } \\
\text { social hierarchy of that day }\end{array}$ & & $\begin{array}{l}\text { Luke 2: } 16 \text { (Shepherds, considered to be of } \\
\text { low social status, visit Jesus) } \\
\text { Luke 2: } 25-38 \text { (Anna and Simeon } \\
\text { remembered, persons of low social status } \\
\text { from a human perspective) }\end{array}$ \\
\hline
\end{tabular}

(*) Evidence does not fit the hypothesis. 
in Luke (six more for Joseph and six less for Mary) and our results would remain significant $(p<0.05)$ by chi-square test $=$ 4.46, two-sided Fisher's Exact test, $r=0.293$, and an odds ratio of 3.41 (95\% Cl, 1.07 to 10.87$)$. Even if some of our assessments were found to have been incorrect, our overall results would likely remain significant statistically. Our results do not prove the source hypothesis but they do suggest that the patterns we found were not a result of random chance. Since the results fit what would be expected under the "source" hypothesis, that should be considered to have received some empirical support, though future research might contradict our findings.

\section{Discussion}

Thus, we think the data suggest that Matthew may have relied on sources near Joseph (e.g., his sons or cousins, depending on Protestant or Roman Catholic views, respectively) or his household, while Luke probably relied upon Mary herself or sources close to Mary (which might have included the author of John and/or the three epistles of John, since some traditions place Mary in the care of John for an extended time after the death of Jesus and the gospel of John mentions Mary several times) or her household. If so, the different genealogies in Matthew and Luke may reflect ancestries associated with Joseph and Mary, or at least recalled by each of them, respectively. Thus, some of the differences in the birth narratives may reflect different parental sources, in part related to their different genders. However, we think that our methodology may have utility across other types of anthropological narratives, past or present, to help determine sources of information and alert anthropologists to potential biases that might be associated with different sources of cultural information or about cultural events. For example, the infancy narratives in the Protoevangelium of James (Anderson, [16] p. 201), the Gospel of Thomas (Isaacs, [10] p. 81), or the Gospel of Pseudo-Matthew or the Qur'an [17] might be investigated in the same way we have done here, as well as many other ancient or more modern documents.

\section{Example 4: Testing an Audience Hypothesis}

\section{Introduction}

Reviewers suggested we test the "audience" hypothesis as well as the "source" hypothesis. One might expect that Jewish audiences would be more interested in Jewish rulers, non-Roman leaders, and Jewish priests/scribes than Greek or Roman audiences who would be more interested in Roman rulers, Roman leaders, and Roman/Greek priests. Herod and his son were Jewish rulers. The priests in Jerusalem were Jewish leaders. Any "king of the Jews" would represent a Jewish leader.

\section{Data}

By those rubrics, Matthew (1: 18 to 2: 23) mentioned Herod eight times (2: 1, 7, 12, 13, 15, 16, 19, 22), Herod's son Archelaus (2: 22), a king or governor of the Jews $(2: 2,6)$, Jewish priests and scribes (2: 4 ) and wise men (by title) from the East two times $(2: 1,7)$, a total of 14 mentions. Luke (1: 5 - 2:40) mentions Herod once (1: 5), a Jewish priest once by title (1: 5), and a king of the Jews once (1: 33), as well as two
Romans leaders $(2: 1,2)$, and doctors of the law at the Temple (2: 46). Those results create a crosstabulation of 14 Jewish references for Matthew and 4 for Luke compared to no Roman references for Matthew and two for Luke. Although Zacharias is mentioned six times, we only counted his priestly title once. Both Matthew and Luke mention angels, so we considered them to be neutral with respect to intended audiences. We did not count Simeon or Anna as Jewish leaders because they had no official titles. Our coding process followed the same procedures as mentioned previously.

\section{Results}

The material in Luke is over three times as lengthy as that in Matthew, so we will present chi-square results with and without weighting on account of the difference in length of material. With unweighted data, we obtain a chi-square value of $5.19(p=0.023)$ with a two-sided Fisher's Exact Test of $p=$ 0.079 and a correlation of $r=0.509(p=0.022)$. With weighted data, we obtain, respectively, values of $14.61(p<0.001), p=$ 0.013 , and $r=0.552(p<0.001)$.

\section{Discussion}

Thus, our results also provide some evidence in support of the "audience" hypothesis. The findings for the audience hypothesis, while often statistically significant, were not as strong as were the findings for the source hypothesis. In sum, there is evidence in favor of both the source and the audience hypotheses, with stronger support for the source hypothesis.

\section{Conclusion}

In example one regarding arrow wounds, we believe we have demonstrated the effective use of statistics with data developed prior to the advent of modern statistical techniques in the early and middle 1900's. Before that time, scholars could present quantitative information, but they had no way to ensure their results were not due to random chance. There may be many other situations in which untested data may be revisited to better understand anthropological issues from before the advent of modern statistical testing. With our last three examples, we used logic to develop rubrics by which to set up comparisons between contrasting theories about various ancient documents or literature. While we used Christian examples, similar techniques could be used with respect to any religion (e.g., Schumm, [18]) or other anthropological literature sources. Scholars on different sides of various debates can argue all they want for or against an idea, but the use of statistics gives them a more systematic way of evaluating the relative strength of different hypotheses or theories. As we found, sometimes contrasting theories may both have elements of validity as found through statistical analysis or both may be somewhat equal in their plausibility. We hope that future scholars will use similar techniques to uncover results for other controversial, even if ancient, issues.

\section{References}

1. Bill JH (1862) Notes on arrow wounds. American Journal of Medical Sciences 154: 366-379.

2. Manson TW (1962) Studies in the gospels and epistles. Westminster Press, Philadelphia, Pennsylvania. 
3. Harrison EF (1971) Introduction to the New Testament (Revised Edition). Eerdmans, Grand Rapids, Michigan.

4. Lohse $E$ (1981) The formation of the New Testament. Abingdon Press, Nashville, Tennessee (translated from the third German edition by M. E. Boring).

5. Perrin N (1974) The New Testament: An introduction - proclamation and parenthesis, myth and history. Harcourt, Brace, \& Jovanovich, New York, New York.

6. Hiebert DE (1977) An introduction to the New Testament: The Pauline epistles (vol. 2). Moody Press, Chicago, Illinois.

7. Fiensy DA (1997) The College Press NIV commentary: New Testament introduction. College Press Publishing Company, Joplin, Missouri.

8. Schumm WR (2021) Confirmation bias and methodology in social science: An editorial. Marriage \& Family Review, online advance.

9. Guthrie D (1990) New Testament introduction (Revised edition). Intervarsity Press, Downers Grove, Illinois.

10. Isaacs ME (1975) Mary in the Lucan infancy narrative. The Way 25: 80-95.

11. Waetjen HC (1976) The genealogy as the key to the Gospel according to Matthew. Journal of Biblical Literature 95: 205-230.

12. Brown RE (1977) The birth of the messiah: A commentary on the infancy narratives in Matthew and Luke. Doubleday and Company, Garden City, New York, United States.
13. Perkins P (1999) Mary in the gospels: A question of focus. Theology Today 56: 297-306.

14. Love SL (1993) The household: A major social component for gender analysis in the Gospel of Matthew. Biblical Theology Bulletin 23: 21-31.

15. Schumm WR (2020) How accurately could early (622-900 C.E.) Muslims determine the direction of prayers (qibla)? Religions 11: 102.

16. Anderson JC (1987) Mary's difference: Gender and patriarchy in the birth narratives. The Journal of Religion 67: 183-202.

17. Mourad, SA (2002) From Hellenism to Christianity and Islam: The origin of the palm-tree story concerning Mary and Jesus in the Gospel of Pseudo-Matthew and the Qur'an. Oriens Christ 86: 206-216.

18. Schumm WR (2020) Reflections of another "hard" sciences student who became an "upstart" social scientist. Insights Anthropol 4: 237-238.

19. Harrison EF (1976) Romans. In: Gaebelein FE, Douglas JD, The expositor's Bible commentary (Vol. 10). Zondervan, Grand Rapids, Michigan.

20. Price JL (1971) Interpreting the New Testament ( $2^{\text {nd }}$ edn). Holt, Rinehart, \& Winston, New York, New York.

21. Robert A, Feuillet A (1965) Introduction to the New Testament. Desclee Company, New York, New York (translated from the French by PW Skehan, EP Arbez, K Sullivan, LJ Dannemiller, EF Siegman, JP McCormick, MRP McGuire). 